\title{
PERBANDINGAN CITRA MRI PEDIS SEQUENCE PROTON DENSITY FAT SATURATED DAN STIR (SHORT TAU INVERSION RECOVERY) POTONGAN SAGITAL
}

\author{
Endah Wahyudiarti ${ }^{1}$, Guntur Winarno ${ }^{2}$, Shinta Gunawati ${ }^{3}$, Legia Prananto ${ }^{4}$, Nursama Heru ${ }^{5}$ \\ ${ }^{I}$ RSUD Chasbullah Abdulmadjid Kota Bekasi \\ 2,3,4,5 Poltekkes Kemenkes Jakarta II, Indonesia \\ Corresponding author: Endah Wahyudiarti \\ e-mail: e.wahyudiarti18@gmail.com
}

\begin{abstract}
Bakcground: The differences in fat suppression MR images between Proton Density Fat Saturated sequence with STIR sequence in MRI pedis sagital view. This research aims to analyze the differences of SNR, CNR, and the details MR images.

Methods: Secondary data were using by non-probability sampling technique with 10 purposive sampling of pedis MR images Proton Density Fat Saturated sequence and STIR sequence sagittal view in DICOM were done by using imageJ software. The instrument of this research consisted of a worksheet and questionnaire.

Result: This research showed SNR $p$ value/sig $0,000<0,05$ and CNR $p$ value/sig $0,575>0,05$. In Proton Density Fat Saturated sequence sagittal view the detail of ekstra-articular fluids value is 1,76 , tendon Achilles value is 2,88 , joint space value is 2,86 and bone marrow value is 2,04 , contrast resolution value is 2,418 , noise ratio value is 2,32 . Pedis MR images of STIR sequence sagittal view the details of ekstra-articular fluids value is 2,92 , tendon Achilles value is 3,28 , joint space value is 2,84 and bone marrow value is 3,4 , contrast resolution value is 3,022 and noise ratio value is 2,44 .

Conclusion: There is a significant difference of SNR value, no significant differences in CNR value and value of MRI pedis sequence Proton Density Fat Saturated sagittal detail is clear enough to show tendon achiles, bone marrow, joint space and not clear to show ekstra-articular fluids. STIR nice to show tendon achiles and bone marrow and clear enough to show ekstraarticular fluids and joint space.
\end{abstract}

Keyword : MRI pedis, Fat Suppresion, Proton Density Fat Saturated sequence, STIR sequence

\section{Pendahuluan}

MRI (Magnetic Resonance Imaging) merupakan salah satu alat penunjang kesehatan di bidang radiologi yang bersifat non-invasif yaitu dengan memanfaatkan atom hydrogen yang berada di dalam tubuh manusia menggunakan medan magnet, gelombang radio dan komputer untuk menghasilkan irisan anatomi tubuh secara multiplanar dengan kontras resolusi yanga sangat baik antara berbagai jaringan lunak tubuh sehingga sangat berguna dalam pencitraan kardiovaskular, muskuloskeletal, neurologis dan onkologis serta dalam mendeteksi abnormalitas berupa tumor atau 
penyempitan jalur jaringan lunak (Brown, Mark A.; Dale, Brian M.; Semelka 2015; Elmaoğlu and Çelik 2012). Dalam evaluasi kualitas gambar, parameter pengukuran kualitas objektif diperlukan agar kualitas gambar dapat dihitung dengan baik sesuai standar algoritma yang telah ditetapkan. Tiga karakteristik yang menentukan kualitas citra yaitu: Signal-to-noise ratio (SNR), Contrastto-noise ratio (CNR) dan Spatial Resolisi (Westbrook, Roth, and Talbot 2011). Spatial resolution merupakan kemampuan untuk membedakan antara dua titik secara terpisah dan jelas, berfungsi untuk melihat ketajaman pada gambar dalam mengidentifikasi obyek yang kecil. SNR yaitu perbandingan antara besarnya amplitudo sinyal dengan amplitudo noise yang mana nilai SNR tersebut digunakan sebagai kriteria untuk menentukan kualitas citra. CNR adalah perbedaan SNR antara organ yang saling berdekatan. CNR yang baik dapat menunjukkan perbedaan daerah yang patologis dan daerah sehat (Arifah, Kartikasari, and Murniati 2017). SNR dan CNR dipengaruhi oleh beberapa faktor yaitu kekuatan medan magnet, densitas proton, time repetion (TR), time echo (TE), flip angle, tipe coil, dan voxel volume (Westbrook and Talbot 2019).

Jaringan lemak mengandung sejumlah proton hidrogen yang menunjukan sinyal tinggi pada pencitraan $T 1$ dan $T 2$ weighted. Sinyal tinggi pada jaringan adiposa tak hanya menutupi sinyal jaringan lain tetapi juga dapat menghasilkan artefak chemical shift. Sequence fat suppression dapat menekan sinyal jaringan adiposa sehingga dapat mengurangi artefak chemical shift dan dapat meningkatkan visualisasi kontras citra MRI. Oleh karena itu, sequence fat suppression dibutuhkan untuk mendiagnosa kelainan muskuloskeletal (Wu et al. 2012; Yang et al. 2015).

Di dalam telapak kaki terdapat otot, ligamen, tulang, saraf, yang dibungkus kulit. Jaringan adiposa tersebar di berbagai bagian dalam tubuh manusia (Gray 2016).

Proton Density Fat Saturated weighted biasa digunakan pada persendian ekstremitas, keuntungannya adalah baik untuk mendeteksi fraktur okultisme pada ekstremitas khususnya pada trauma tulang, ligamen, tendon dan tulang rawan sendi. Teknik penekanan pada lemak membutuhkan instrumen MR dengan kekuatan magnet yang tinggi (stabil)(Abdulla, Sarah. Clarke 2018; Lee 2016; Wu et al. 2012). Short Tau Inversion Recovery (STIR) adalah salah satu teknik fat-suppression yang merupakan bagian inversion recovery, digunakan untuk mengurangi sinyal lemak sehingga untuk kelainan bone marrow dan kelainan organ yang dikelilingi oleh lemak dapat teridentifikasi dengan baik. (Brown, Mark A.; Dale, Brian M.; Semelka 2015; Westbrook, Roth, and Talbot 2011). STIR memiliki keuntungan tidak sensitif terhadap medan magnet inhomogen (dapat digunakan untuk medan magnet rendah), dapat digunakan untuk pemeriksaan dengan field of view besar (misalnya spine), baik untuk diagnosa bone marrow edema, baik untuk memperlihatkan spinal cord injury, fraktur dan osteoporosis, penekanan lemak yang homogen pada pasien yang menggunakan metalimplant, nilai specific absorption rate (SAR) tinggi, memproduksi signal fat suppression yang seragam (dapat menekan lemak pada semua jaringan), insensitivity tinggi terhadap Bo inhomogeneity (Dalto et al. 2020).

Tujuan dari penelitian ini adalah untuk menganalisis perbedaan nilai SNR, CNR dan detail citra MRI pedis sequence Proton Density Fat Saturated potongan sagital dengan STIR potongan sagital.

\section{Metode penelitian}

Desain penelitian yang digunakan dalam penelitian ini adalah analitik kuantitatif dan retrospective. Populsi dari penelitian ini adalah seluruh pasien MRI pedis di Instalasi Radiologi Rumah Sakit Medistra pada bulan Januari 2019-Desember 2020. Sampel dalam penelitian ini adalah 10 sampel Purposive Sampling. Kriteria inklusi partisipan dalam penelitian ini adalah pasien dewasa, usia diatas 18 tahun dan kriteria ekslusi partisipan dalam penelitan ini adalah pasien usia dewasa dengan kelainan bawaan (Anomali konginetal).

\section{Hasil}

Penelitian ini dilakukan di Instalasi Radiologi Rumah Sakit Medistra. Data yang 
didapat telah melakukan standar operational prosedur pemeriksaan MRI pedis.

Pesawat MRI yang digunakan merk GE HDXt superkonduktor dengan kuat medan magnet 1,5 Tesla dan menggunakan quadfoot coil.

Sampel yang digunakan berjumlah 10 purposive sampling MRI pedis sequence Proton Density Fat Saturated potongan sagital dan 10 purposive sampling MRI pedis STIR potongan sagital disimpan dalam bentuk DICOM dan dilakukan analisis penghitungan nilai individual pixel dan nilai mean-nya dengan software image.

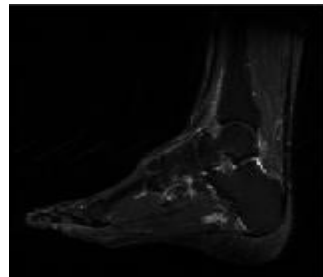

A

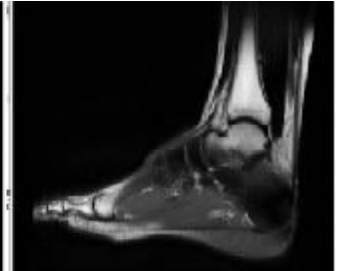

B
Gambar 1. (A) Citra MRI pedis sequence STIR Potongan Sagital. (B) Citra MRI pedis sequence Proton Density Fat Saturated potongan sagital

\section{Perhitungan secara kuantitatif.}

Penghitungan menggunakan software Image J pada 10 titik citra Proton Density Fat Saturated potongan sagital dan citra STIR potongan sagital, titik 1 sampai dengan titik 9 diletakan pada tulang pedis dan titik 10 diletakan pada soft tissue pedis. 10 titik ROI pada objek pedis yaitu 1/3 distal tulang cruris, tulang talus, tulang Head of talus, tulang calcaneus, tulang navicular, tulang cuneiforme, tulang metacarpal, tulang phalang distal, tulang phalang medial, soft tissue pedis. Dari penghitungan 10 titik ROI dengan software imageJ didapatkan nilai mean objek (sinyal), nilai standar deviasi objek(noise) dan standar deviasi background(noise background). Nilai tersebut kemudian digunakan untuk menghitung nilai Signal to Noise Ratio (SNR) dan Contras to Noise Ratio (CNR).
Tabel 1. Nilai Mean(sinyal) per ROI objek

\begin{tabular}{llllllllllll}
\hline \multirow{3}{*}{ Sequence } & \multicolumn{1}{l}{ Titik Sampel Sampel Sampel Sampel Sampel Sampel Sampel Sampel Sampel Sampel } \\
& ROI & 1 & 2 & 3 & 4 & 5 & 6 & 7 & 8 & 9 & 10 \\
\hline
\end{tabular}

R011 3103,00 547,22 2533,002315,33 534,56 2701,112549,333252,11 534,44 2970,22 ROL2 1709,33 777,67 1975,441731,78 719,22 1891,3322275,332370,78 877,56 2300,67 R0I3 897,33 2139,001325,00 563,11 1576,891109,561882,111371,781060,781947,89

PROTON ROI4 753,33 1924,002176,11 876,33 2012,33 534,89 760,00 732,89 2510,561584,33 DENSITY

FAT R015 712,11 2769,56 639,22 437,44 2254,33 520,89 1121,33 617,22 1940,331612,67 SATURATED ROI6 658,67 1674,89 471,33 495,22 2130,78 521,00 648,67 618,22 1742,001403,56 POTONGAN

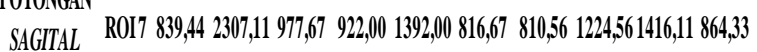
R0I8 2001,222167,071949,002178,222184,672650,111956,891691,782920,56 895,22 R0I9 1754,002046,44 2786,782559,781510,443001,442454,001751,671813,44 961,00 R0110 890,22 1038,67 937,22 924,56 890,56 929,44 836,67 952,11 914,78 806,89 ROI1 281,22 $552,56 \quad 158,89 \quad 143,44 \quad 312,67 \quad 177,56 \quad 215,00 \quad 281,33 \quad 177,89 \quad 286,89$ R0I2 251,89 262,11 186,89 182,22 238,33 174,11 196,00 290,00 155,44 283,33 R0I3 254,11 428,00 245,44 181,44 195,56 127,22 238,67 274,44 135,33 243,00 ROI4 221,00 228,44 247,44 199,22 221,33 260,89 232,67 206,44 $114,56 \quad 223,56$ STIR POTONGAN

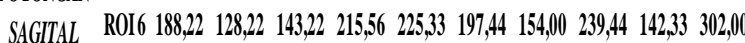

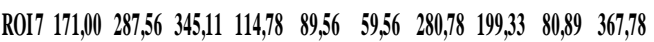
ROI8 175,44 417,78 457,67 239,89 266,56 373,56 280,00 262,67 209,67 355,22 ROI9 170,22 213,56 339,11 237,67 218,11 416,56 526,78 197,78 $149,56 \quad 317,67$ R0I10 308,78 324,44 368,78 $301,11 \quad 289,78 \quad 308,56 \quad 288,78 \quad 322,56 \quad 341,22 \quad 316,22$

Data mean, standar deviasi objek dan standar deviasi background di buat rata-rata nilai dan dimasukan kedalam rumus pengitungangan untuk mendapatkan nilai SNR dan CNR dapat dilihat pada tabel 2.

$\mathrm{SNR}=$ signal objek

$$
\text { noise objek }
$$

$\mathrm{CNR}=\quad$ SNR1-SNR2

noise background 
Tabel 2. Nilai Mean objek, standar deviasi objek, standar deviasi background, SNR dan CNR

\begin{tabular}{|c|c|c|c|c|c|c|c|c|c|c|}
\hline Sampel & Rean PDAS & Rata-rata & Rata-rata & Rata-ratata & $\begin{array}{l}\text { Ratararata } \\
\text { stter } \\
\text { background }\end{array}$ & $\begin{array}{l}\text { Ratararata } \\
\text { stder } \\
\text { background }\end{array}$ & $\begin{array}{l}\text { SNR } \\
\text { PDIS }\end{array}$ & $\begin{array}{l}\text { SNR } \\
\text { STIR }\end{array}$ & & $\begin{array}{l}\text { CNR } \\
\text { STIF }\end{array}$ \\
\hline & & & & & PDES & stir & & & & \\
\hline 1 & $2.104,0$ & $2,587,445$ & 522,878 & 242,628 & 167,995 & 59,155 & 29 & 7,9 & 0,75 & 0,17 \\
\hline 2 & $1.662,9$ & $2,220,332$ & 525,222 & 23,087 & 9,399 & 56,515 & 25 & 5.9 & 0,29 & 0,53 \\
\hline 3 & $1,387,3$ & $2,323,221$ & 624,103 & 329,027 & 80,485 & 492,825 & 28 & 8,1 & 0,76 & 1,71 \\
\hline 4 & $1.386,5$ & $2,153,555$ & 367,522 & 255,634 & 625,675 & 619,575 & 17,6 & 4,8 & 3,82 & 3,55 \\
\hline 5 & $1.262,5$ & $2,139,445$ & 337,466 & 407,554 & 85,625 & 5,028 & 31,8 & 6,7 & 1,04 & 1,09 \\
\hline 6 & $1,036,4$ & $1,935,776$ & 514,518 & 443,556 & 39,775 & 34,335 & 26,4 & 6,9 & & 8,6 \\
\hline 1 & $1.157,0$ & $1,996,335$ & 384,022 & 27,861 & 62,425 & 461,375 & 16,4 & 3,8 & & 3,8 \\
\hline 8 & $2,059,5$ & $3,038,446$ & 774,085 & 426,288 & 5,633 & 503,475 & 26,7 & 7,6 & & $11,5^{\circ}$ \\
\hline 9 & 2.063 .9 & $2,787,002$ & 940,547 & 522,983 & 733,375 & 446,425 & 19,6 & 6,1 & & 0,93 \\
\hline 10 & 912,1 & $3,170,223$ & 221,682 & 177,617 & 510,725 & 590,825 & 32,9 & 9,5 & & 0,36 \\
\hline
\end{tabular}

\section{a. Uji Normalitas}

Uji ini dilakukan untuk mengetahui apakah data yang diperoleh memiliki distribusi normal atau tidak dan untuk menentukan uji statistik yang tepat.

Tabel 3. Hasil Uji Normalitas SNR

\begin{tabular}{ccc}
\hline Sequence & $p$ value/sig & Makna \\
\hline $\begin{array}{c}\text { Poton Density Fat } \\
\text { Saturated } \\
\text { potongan sagital }\end{array}$ & 0,408 & Normal \\
$\begin{array}{c}\text { STIR potongan } \\
\text { sagital }\end{array}$ & 0,991 & Normal \\
\hline
\end{tabular}

Berdasarkan tabel 3 diperoleh nilai $p$ value/signifikansi SNR pada MRI pedis sequence Proton Density Fat Saturated potongan sagital dan sequence STIR potongan sagital > 0.05, dapat disimpulkan bahwa data berdistribusi normal. Selanjutnya analisis statistik dengan menggunakan uji statistik Paired T-Test.
Tabel 4. Hasil Uji Normalitas CNR

\begin{tabular}{ccc}
\hline Sequence & p value/sig & Makna \\
\hline $\begin{array}{c}\text { SNR Poton Density } \\
\text { Fat Saturated } \\
\text { potongan sagital }\end{array}$ & 0,015 & $\begin{array}{c}\text { Tidak } \\
\text { Berdistribusi } \\
\text { Normal }\end{array}$
\end{tabular}

\section{SNR STIR}

potongan sagital

0,008

Tidak

Berdistribusi

Normal

Berdasarkan tabel 4, diperoleh nilai $\mathrm{p}$

value/signifikansi CNR pada citra MRI pedis

sequence Proton Density Fat Saturated potongan sagital dengan sequence STIR

potongan sagital $<0.05$, disimpulkan bahwa data tidak berdistribusi normal. Selanjutnya analisis statistik dengan menggunakan uji statistic Wilcoxon.

\section{b. Uji Statistik}

Uji Paired Sample T-Test adalah pengujian yang digunakan untuk data berdistribusi normal. Uji wilcoxon merupakan uji nonparametris untuk data yang berdistribusi tidak normal.

Hipotesis :

Ho : Tidak Ada perbedaan citra MRI pedis antara sequence Proton Density Fat Saturated potongan sagital dengan citra sequence STIR potongan Sagital.

$\mathrm{Ha}$ : Ada perbedaan citra MRI pedis antara sequence Proton Density Fat Saturated potongan sagital dengan citra sequence STIR potongan Sagital.

Kriteria Uji $(\alpha: 5 \%)$ :

Tolak : Ho jika $\mathrm{p}-$ value $<\alpha$

Terima : Ho jika $\mathrm{p}-$ value $>\alpha$

Tabel 5. Uji statistik SNR Paired T-Test Sampel

\begin{tabular}{cc}
\hline Sequence & $p$ value/sig \\
\hline & \\
Poton Density Fat & 0,000 \\
$\begin{array}{c}\text { Saturated potongan } \\
\text { sagital }- \text { STIR } \\
\text { potongan sagital }\end{array}$ & \\
\hline
\end{tabular}


Berdasarkan table 5, nilai SNR pada sequence Proton Density Fat Saturated potongan sagital dengan sequence STIR potongan sagital memiliki $p$ value/sig 0,000 $<0.05$ artinya ada perbedaan yang signifikan.

Tabel 6. Uji statistik Wilcoxon nilai CNR

\begin{tabular}{cc} 
Sequence & p value/sig \\
\hline Poton Density Fat & \\
Saturated potongan & 0,575 \\
sagital - STIR & \\
potongan sagital & \\
\hline
\end{tabular}

Berdasarkan tabel 6, nilai CNR pada sequence Proton Density Fat Saturated potongan sagital dengan sequence STIR potongan sagital memiliki $p$ value/sig 0,575 $>0.05$ artinya tidak memiliki perbedaan yang signifikan.

\section{Penghitungan secara kualitatif}

Analisa kualitatif dilakukan dengan menggunakan kuisioner yang diberikan kepada 5 orang dokter spesialis radiologi untuk menilai detail citra MRI pedis (Cairan ekstra artikular, tendon achiles, tulang sendi, bone marrow), kontras resolusi (perbedaan intensitas pada tulang-tulang pedis, pada soft tissue pedis dan antara tulang-tulang pedis dengan soft tissue pedis) dan noise ratio dari citra MRI pedis. Setiap kuisioner terdapat tiga lampiran pertanyaan dengan rentang nilai 1 4.

Tabel 9 Rata-rata Nilai Kuisioner Citra MRI Pedis Sequence Proton Density Fat Saturated potongan sagital dan STIR potongan sagital

\begin{tabular}{|c|c|c|}
\hline $\begin{array}{c}\text { Penilaian } \\
\text { Informasi Citra }\end{array}$ & PDFS & STIR \\
\hline $\begin{array}{l}\text { Cairan ekstra } \\
\text { artikular }\end{array}$ & 1,76 & 2,92 \\
\hline Tendon Achiles & 2,88 & 3,28 \\
\hline Ruang Sendi & 2,86 & 2,84 \\
\hline Bone marrow & 2,04 & 3,4 \\
\hline $\begin{array}{l}\text { Kontras resolusi } \\
\text { citra MRI pedis }\end{array}$ & 2,418 & 3,022 \\
\hline $\begin{array}{c}\text { Noise Ratio citra } \\
\text { MRI pedis }\end{array}$ & 2,32 & 2,44 \\
\hline
\end{tabular}

\section{Pembahasan}

1. Berdasarkan hasil analisa Image J dan perhitungan statistik didapatkan hasil penghitungan kuantitatif SNR didapatkan nilai $p$ value/sig bernilai $0,000<0.05$. Sehingga dapat disimpulkan bahwa ada perbedaan citra MRI pedis sequence Proton Density Fat Saturated potongan sagital dengan citra sequence STIR potongan sagital yang signifikan. Diketahui dari hasil penghitungan software imageJ pada tabel 1 nilai mean per ROI objek, terdapat dua nilai intensitas pada tulang pedis yaitu nilai intensitas tinggi tulang pedis yaitu 890,222-3252,111, nilai intensitas rendah tulang pedis yaitu 437,444-890,222. Nilai intensitas soft tissue pedis yaitu: 806,889-1038,667. Perbedaan yang signifikan terdapat pada nilai intensitas tinggi dari tulang pedis pada citra MRI pedis sequence Proton Density Fat Saturated potongan sagital. Nilai intensitas tinggi (hiperintens) dari tulang pedis menyebabkan akumulasi nilai mean objek menjadi tinggi. Sehingga menyebabkan nilai SNR menjadi tinggi. Nilai SNR didapatkan dari akumulasi nilai mean objek dibagi nilai standar deviasi objek. Sedangkan pada sequence STIR tidak terdapat citra dengan intensitas tinggi pada tulang pedis. Nilai intensitas tulang pada citra MRI pedis sequence STIR yang dihasilkan software imageJ yaitu: 59,556-552,556. Perbedaan intensitas citra MRI pedis pada gambar 1 tampak pada sequence Proton Density Fat Saturated potongan sagital dikarenakan adanya kegagalan pulsa fat saturated menekan sinyal lemak. Menurut Dr. Sarah Abdulla dan Dr. Christopher Clarke dalam buku FRCR Physics Notes: 2018, sekuen fat saturated memanfaatkan frekuensi lamor yang berbeda dari lemak dan air dengan menerapkan pulsa RF maksimal untuk meniadakan sinyal lemak. Jika frekuensi puncak dari lemak sedikit berbeda disebabkan oleh geometri anatomi kontur yang berubah cepat (Contoh: pergelangan kaki dan kaki) atau magnetic field gradient menyimpang maka pulsa RF akan mengalami kegagalan dalam proses penekanan lemak sehingga sinyal lemak ada dapat ditekan (supression) dengan baik dan ada yang tidak dapat ditekan (supression) dengan baik oleh pulsa fat 
saturation. Oleh sebab itu, terdapat intensitas pada citra MRI pedis yang tidak sesuai dengan intensitas citra yang seharusnya terbentuk pada MRI pedis.

Area yang mengandung jaringan adiposa tampak gelap atau intensitas rendah (hipointens) dalam citra MRI Proton Density Fat Saturated. Tampilan citra MRI Proton Density Fat Saturated dan STIR adalah sebagai berikut:

$\begin{array}{ll}\text { Bone marrow } & \text { : Gelap/ hipointes } \\ \text { Otot } & : \text { Abu-abu/ isointens } \\ \text { Fat } & : \text { Gelap/ hipointens } \\ \text { Fluid } & : \text { Terang/ hiperintens } \\ \text { Darah : Gelap/ hipointens } \\ \text { Tulang } & : \text { Gelap/ hipointens } \\ \text { Udara : Gelap/ hipointens }\end{array}$

Dengan penambahan pulsa fat saturated pada sequence Proton density, patologis tampak terang/ hiperintens(Proton Density Fat Saturated.MRI Master.pdf n.d.; Proton Density Fat Saturated dan STIR.MRI Master.pdf n.d.).

2. Berdasarkan tabel 6, diperoleh hasil uji statistik yang memiliki $p$ value/sig bernilai $0,575>0.05$, artinya nilai CNR pada sequence Proton Density Fat Saturated potongan sagital dengan sequence STIR potongan sagital tidak memiliki perbedaan yang signifikan. Hal ini menunjukan perbedaan kontras dan noise antara citra MRI pedis sequence Proton Density Fat Saturated potongan sagital dengan sequence STIR potongan sagital tidak jauh berbeda.

3. Menurut penilaian subjektif 5 orang responden dokter radiologi terhadap citra MRI pedis :

a. Sequence Proton Density Fat Saturated potongan sagital detail citra MRI pedis pertama adalah tendon achiles dengan nilai 2,88 , kedua adalah ruang sendi dengan nilai 2,86 , ketiga adalah bone marrow dengan nilai 2,04 dan terakhir adalah cairan ekstra artikular dengan nilai 1,76 , kontras resolusi citra MRI pedis cukup jelas dengan nilai 2,418 dan noise ratio cukup jelas dengan nilai 2,32.

b. Sequence STIR potongan sagital detail citra MRI pedis pertama adalah bone marrow dengan nilai 3,4, kedua adalah tendon achiles dengan nilai 3,28 , ketiga adalah cairan ekstra artikular dengan nilai 2,92 dan terakhir ruang sendi dengan nilai 2,84 , kontras resolusi citra
MRI pedis baik dengan nilai 3,022 dan noise ratio cukup jelas dengan nilai 2,44 .

\section{Kesimpulan}

1. Terdapat perbedaan yang signifikan pada nilai SNR citra MRI pedis sequence Proton Density Fat Saturated potongan sagital dengan sequence STIR potongan sagital, nilai $p$ value/sig $\mathrm{SNR}$ adalah $0,000<\alpha$.

2. Tidak terdapat perbedaan yang signifikan pada nilai CNR citra MRI pedis sequence Proton Density Fat Saturated potongan sagital dengan sequence STIR potongan sagital, nilai $p$ value/sig CNR adalah 0,522 > $\alpha$.

3. Detail citra MRI pedis sequence Proton Density Fat Saturated cukup jelas untuk menilai tendon achiles, ruang sendi dan bone marrow serta kurang jelas untuk menilai cairan ekstra artikular. Sequence STIR potongan sagital jelas sampai sangat jelas untuk menilai bone marrow dan tendon achiles serta cukup jelas untuk menilai ruang sendi dan cairan ekstra artikular. Sequence Proton Density Fat Saturated potongan sagital memiliki kontras resolusi citra MRI pedis cukup baik dan noise ratio yang cukup baik. Sequence STIR potongan sagital memiliki kontras resolusi yang baik dan noise ratio yang cukup baik.

\section{Daftar Pustaka}

Abdulla, Sarah. Clarke, Christopher. 2018. "FRCR Physics Notes."

Arifah, Ahda Nur, Yeti Kartikasari, and Emi Murniati. 2017. "Comparative Analysis of the Value of Signal To Noise Ratio (Snr) At Mri Ankle Joint Examination Using Quad Knee Coil and Flex/Multipurpose Coil." JImeD 3(1): 220-24.

https://www.researchgate.net/publication 1328389266_Analisis_Perbandingan_Nil ai_Signal_to_Noise_Ratio_SNR_pada_P emeriksaan_MRI_Ankle_Joint_dengan_ Menggunakan_Quad_Knee_Coil_dan_Fl exMultipurpose_Coil.

Brown, Mark A.; Dale, Brian M.; Semelka, Richard C. 2015. MRI : Basic Principles and Applications. Wiley-Blackwell. 
Dalto, Vitor Faeda et al. 2020. "Comparison between Stir and T2-Weighted Spair Sequences in the Evaluation of Inflammatory Sacroiliitis: Diagnostic Performance and Signal-to-Noise Ratio." Radiologia Brasileira 53(4): 223-28.

Elmaoğlu, Muhammed, and Azim Çelik. 2012. MRI Handbook MRI Handbook.

Gray. 2016. GRAY'S Anatomy The Anatomical Basis of Clinical Practice. ed. Susan Stranding.

Lee, se won. 2016. "Musculoskeletal Injuries and Conditions." : 383-401.

"Proton Density Fat Saturated.MRI Master.Pdf."

"Proton Density Fat Saturated Dan STIR.MRI Master.Pdf."

Westbrook, Catherine, Carolyn Kaut Roth, and John Talbot. 2011. MRI in Practice. 4th ed. Wiley-Blackwell.

Westbrook, Catherine, and John Talbot. 2019. MRI in Practice. 5th ed. WileyBlackwell.

Wu, Jing, Ling-Quan Lu, Jian-Ping Gu, and Xin-Dao Yin. 2012. "The Application of Fat-Suppression MR Pulse Sequence in theDiagnosis of Bone-Joint Disease." International Journal of Medical Physics, Clinical Engineering and Radiation Oncology 01(03): 88-94.

Yang, Guang et al. 2015. "Fat-Suppresion Techniques for 3-T MR Imaging of The Muculoskeletal System.” 344(6188): 1173-78. 